\title{
The linearity problem of protein measurement and hook effect in albumin measurement from body fluids
}

\section{Hamit Yasar Ellidag}

Department of Clinical Biochemistry, Antalya Training and Research Hospital, Antalya, Turkey

$S^{\mathrm{e}}$ erum total protein (sPRT) and serum albumin (sALB) tests and micro total protein (MTP) and micro albumin (MA) tests for various body fluids are routinely performed in clinical biochemistry laboratories. These analyses are crucial for screening kidney pathologies from urine samples and for their diagnosis, prognosis, and treatment planning [1]; for differentiating exudate and transudate from pleural fluids [2]; and for investigating central nervous system infections and assessing blood-brain barrier functions from the cerebrospinal fluid (CSF) [3].

Levels of sPRT and sALB are high enough to be expressed in grams, and they vary in a certain range. Levels of albumin and protein in body fluids are relatively lower and have a more variable range. Kits have been therefore developed for measuring low levels of MTP and MA in body fluids. However, the biggest handicap is the aforementioned highly variable range of MTP and MA in body fluids, and the highly puzzling nature

\section{Table 1. Analysis of pleural fluid}

\begin{tabular}{lcc}
\hline Parameter & Value & Unit \\
\hline First measurement & & \\
SALB & 2.4 & $\mathrm{~g} / \mathrm{dL}$ \\
MTP & 739 & $\mathrm{mg} / \mathrm{dL}$ \\
Second measurement & & \\
MTP (1:10 dilution) & 3741 & $\mathrm{mg} / \mathrm{dL}$ \\
SPRT & 4.3 & $\mathrm{~g} / \mathrm{dL}$ \\
\hline
\end{tabular}

SALB: Serum Albumin

MTP: Micro Total Protein

sPRT: Serum Protein of the results obtained. For instance, a routine analysis of pleural fluid is given in Table 1.

As seen in Table 1, the level of pleural albumin was $2.400 \mathrm{mg} /$ $\mathrm{dL}$, whereas that of pleural MTP was $739 \mathrm{mg} / \mathrm{dL}$. However, because albumin is itself a protein, the level of it cannot exceed the level of total protein. When the sample was diluted 1:10 and a second measurement of MTP was performed along with a measurement of sPRT, the results obtained were consistent with the level of albumin determined earlier (Table 1, second measurement).

In our laboratory, levels of sPRT, sALB, MTP, and MA are measured using a Beckman Coulter AU5800 autoanalyzer (Beckman Coulter Inc. CA, USA) and kits from the same company. The SPRT levels are determined with the biuret method (analytic range, 3-12 g/dL), MTP levels (urinary/CSF protein) using pyrogallol red (analytic range, 1-200 mg/dL), sALB levels using bromocresol green (analytic range or linearity, 1.5-6.0 $\mathrm{g} / \mathrm{dL}$ ), and MA levels with the immunoturbidimetric method (analytic range or linearity, $0.5-30.0 \mathrm{mg} / \mathrm{dL}$ ) according to the kits datasheets. The datasheets of these kits refer to a prozone effect (hook effect) only for MA measurements $\geq 600 \mathrm{mg} / \mathrm{dL}$. Note that such an effect is not mentioned for MTP measurements. Furthermore, no warning message associated with the said analysis is present in the laboratory information system with which the device is connected.

Therefore, a serial dilution (1:1, 1:2, 1:4, 1:16, 1:32, and 1:64) analysis of a random serum sample was performed for all protein and albumin tests at our laboratory (Table 2).

As observed in Table 2, false results are obtained for MTP levels approximately $>400 \mathrm{mg} / \mathrm{dL}$ and for MA levels $>60 \mathrm{mg} / \mathrm{dL}$.

Address for correspondence: Hamit Yasar Ellidag, MD. Department of Clinical Biochemistry, Antalya Training and Research Hospital, Antalya, Turkey Phone: +90 5054952155 E-mail: hayael1980@hotmail.com ORCID: 0000-0002-7511-2547

Submitted Date: May 09, 2018 Accepted Date: June 25, 2018 Available Online Date: September 19, 2018

${ }^{\circ}$ Copyright 2018 by International Journal of Medical Biochemistry - Available online at www.internationalbiochemistry.com 
Table 2. Serial dilution analysis of a random serum sample

\begin{tabular}{|c|c|c|c|c|c|}
\hline \multicolumn{3}{|c|}{ Protein $(\mathrm{g} / \mathrm{dL})$} & \multicolumn{3}{|c|}{ Albumin (g/dL) } \\
\hline $\begin{array}{l}\text { Measured } \\
\text { Value }\end{array}$ & $\begin{array}{l}\text { Expected } \\
\text { Value }\end{array}$ & $\begin{array}{c}\text { Difference } \\
\text { (\%Variance) }\end{array}$ & $\begin{array}{l}\text { Measured } \\
\text { Value }\end{array}$ & $\begin{array}{l}\text { Expected } \\
\text { Value }\end{array}$ & $\begin{array}{l}\text { Difference } \\
\text { (\%Variance) }\end{array}$ \\
\hline 7.6 & 7.6 & - & 4.0 & 4.0 & - \\
\hline 3.9 & 3.8 & $-0.1(\% 2.6)$ & 2.1 & 2.0 & $-0.1(\% 5)$ \\
\hline 2.0 & 1.9 & $-0.1(\% 2.7)$ & 1.0 & 1.0 & $0(\% 0)$ \\
\hline 1.1 & 0.9 & $-0.2(\% 22)$ & 0.4 & 0.5 & $0.1(\% 20)$ \\
\hline 0.6 & 0.4 & $-0.2(\% 50)$ & 0.2 & 0.25 & $0.05(\% 20)$ \\
\hline 0.4 & 0.2 & $-0.2(\% 100)$ & 0.1 & 0.125 & $0.025(\% 20)$ \\
\hline 0.2 & 0.1 & $-0.1(\% 100)$ & 0 & 0.06 & - \\
\hline \multicolumn{3}{|c|}{ MTP (mg/dL) } & \multicolumn{3}{|c|}{$M A(m g / d L)$} \\
\hline $\begin{array}{l}\text { Measured } \\
\text { Value }\end{array}$ & $\begin{array}{l}\text { Expected } \\
\text { Value }\end{array}$ & $\begin{array}{c}\text { Difference } \\
\text { (\%Variance) }\end{array}$ & $\begin{array}{l}\text { Measured } \\
\text { Value }\end{array}$ & $\begin{array}{l}\text { Expected } \\
\text { Value }\end{array}$ & $\begin{array}{l}\text { Difference } \\
\text { (\%Variance) }\end{array}$ \\
\hline 630.7 & 7.600 & $-6.970(\% 1.106)$ & 3.97 & 4.100 & $-4.096(\% 103.174)$ \\
\hline 741.6 & 3.800 & $-3.058(\% 412)$ & 38 & 2050 & $-2.012(\% 5.294)$ \\
\hline 819.7 & 1.900 & $-1080(\% 132)$ & 108 & 1025 & $-917(\% 849)$ \\
\hline 750 & 950 & $-200(\% 27)$ & 92 & 512.5 & $-420(\% 457)$ \\
\hline 447 & 475 & $28(\% 6.2)$ & 99 & 256 & $-157(\% 158)$ \\
\hline 231 & 237 & $6(\% 2.5)$ & 87 & 128 & $-41(\% 47)$ \\
\hline 126 & 119 & $-7(\% 5.5)$ & 63 & 64 & $-1(\% 1.5)$ \\
\hline 64 & 59 & $-5(\% 8)$ & 37 & 32 & $-5(\% 13.5)$ \\
\hline 33 & 30 & $-3(\% 9)$ & 20 & 16 & $-4(\% 20)$ \\
\hline 16 & 15 & $-1(\% 6)$ & 9.8 & 8 & $1.8(\% 22.5)$ \\
\hline
\end{tabular}

The course of action for samples with MTP levels $>400 \mathrm{mg} / \mathrm{dL}$ should be to use the sPRT kit instead, and if the resulting measurement is lower than $1 \mathrm{~g} / \mathrm{dL}$, to use the MTP kit following a 1:10 dilution. However, this procedure is not very practical. Conversely, performing SPRT and MTP analyses simultaneously on the sample received, and then determining the dilution factor accordingly would be more sensible in terms of time. With respect to albumin, once the total protein level of the sample is established, estimating the levels of albumin becomes easier. Further, according to our serial dilution analysis, sALB levels can be correctly assessed up to $100 \mathrm{mg} / \mathrm{dL}$.

\section{References}

1. Biljak VR, Honović L, Matica J, Krešić B, Vojak SŠ. The role of laboratory testing in detection and classification of chronic kidney disease: national recommendations. Biochem Med (Zagreb) 2017;27:153-76. [CrossRef]

2. Tarn AC, Lapworth R. Biochemical analysis of pleural fluid: what should we measure? Ann Clin Biochem 2001;38:311-22.

3. Hühmer AF, Biringer RG, Amato $H$, Fonteh AN, Harrington MG. Protein Analysis in Human Cerebrospinal Fluid: Physiological Aspects, Current Progress and Future Challenges. Disease Markers 2006;22:3-26. [CrossRef] 